\title{
"I AM MAKING MYSELF REMEMBER THAT AWFUL TIME": JUVENILIA, HIROSHIMA, AND THE POLITICS OF PEACE
}

\author{
Caroline Lieffers \\ Assistant Professor, The King's University
}

\author{
Cherry petals fall \\ Those that cling to the bough \\ In their turn will fall. \\ - Sumie Kuramoto, Children of the A-Bomb
}

\begin{abstract}
We, the Japanese people, desire peace for all time and are deeply conscious of the high ideals controlling human relationship, and we have determined to preserve our security and existence, trusting in the justice and faith of the peace-loving peoples of the world.

- Japanese Constitution (1947), Preamble
\end{abstract}

$\mathrm{O}_{\mathrm{N}}$ THE morning of 6 August 1945, Hiroshima's residents experienced the unimaginable horror of being the first victims of atomic warfare. The exact number of casualties remains unknown, but some 70,000 people may have perished in the initial blast, and within five years perhaps 200,000 were dead from the effects of injuries and radiation (U.S. Department of Energy). Even the mosquitoes, some early reports poignantly noted, were destroyed that day (Hook 19). As American forces occupied the country, the Japanese press was put under a strict code of censorship. Lasting until 1949, it banned the publication of any media that "might, directly or by inference, disturb the public tranquillity" or be construed as "destructive criticism" of the Allied Powers (Braw 42).

Yet even within this difficult intellectual context, Arata Osada was planning a new project. ${ }^{1}$ A professor of education at Hiroshima University, he worked with several dozen schools in the city to solicit between one and two thousand first-hand accounts from young people who had survived the atomic bombing. As the stories

(cc) Lieffers. This article is distributed under a Creative Commons Attribution-NonCommercialNoDerivatives 4.0 International Licence (creativecommons.org/licenses/by-nc-nd/4.0/).

Journal of Juvenilia Studies 4.I (202I), PP. 5I-73. DOI: I0.29I74/jjs5 I 


\section{JJS December (202I) Special Issue: Juvenilia, Trauma, and Intersectionality}

poured in from mid-March to mid-June of 1951, Osada worked with his sons and several college students to edit and compile 105 of them into a book (Osada, Preface xxxiii; Bajo). Genbaku no ko: Hiroshima no shonen shojo no uttae [Children of the A-Bomb: Testament of the Boys and Girls of Hiroshima] was published later that year. The first English edition was published in 1959 from Tokyo-based Uchida Rokakuho, while an abridged edition from G. P. Putnam's Sons in 1963 gave the book wider distribution in the United States. Though the text had only modest popularity with American audiences, it was translated into fourteen languages, and as of 2015, an estimated 270,000 copies had been sold worldwide ("Hiroshima ... Paper Monuments").

Children of the $A$-Bomb is a remarkable book, a compilation of emotionally gripping and philosophically poignant expressions from young writers ranging from about fourth grade to university age; they were between approximately four and eighteen years old at the time of the atomic blast. But the testimonials also served larger political ends. They spoke to a new, peace-loving identity for Japan and the development of a culture of "victim consciousness" (Orr), part of a larger transformation that Lisa Yoneyama has summarised as "a change from a country of masculinized prowess to feminized innocence" (38). Innocent children's victimhood was also an important vehicle for Osada's larger dedication to the causes of denuclearisation and the global peace movement, which were likewise symbolised in the city of Hiroshima itself. Osada would reportedly inscribe copies of the book with the note, "Listen to the voice of God's small children" (Tashiro), and the letter of thanks he wrote to each of the juvenile contributors made his aims clear:

When I think of you taking up your pen ... when I imagine how the remembered figures of those whom you lost came before your eyes, and how you must have talked to them, I feel that these words which you have written are a sort of proyer [sic] for the tranquil repose of their souls. If we can publish them, both within our country and without, these words of yours will build in people's hearts an enduring, spiritual, Memorial Tower which will surely give joy to the spirits of those who have died. And I believe that not only in Hiroshima, but in all of Japan, and in all the world, people of conscience will offer their hearts' prayers at this Memorial Tower which you have built. $(\mathrm{x})^{2}$

Osada articulated his investment in a kind of non-denominational spirituality, as well as a larger vision of peace education that might speak to and benefit all humanity, a project that Yoneyama terms "nuclear universalism" (15). The children's voices, Osada wrote, might help "make this tragedy not the end but the beginning of the new world" ("Prof. Osada's Preface" xxxii). 


\section{Lieffers | Juvenilia, Hiroshima, and the Politics of Peace}

And yet, the accounts in Children of the A-Bomb, as well as the book's reception and afterlife, demonstrate that this could never be a simple project. The "peace" for which the children were writing would be articulated in several different, but interrelated registers: in Japan's new identity and Hiroshima's re-branding as a city of peace, for example; in the often left-leaning anti-nuclear and peace education movements in Japan and abroad; and in the young writers' own, deeply personal attempts to derive meaning from their pain, to prevent further war, or simply to carry on. By being asked to sublimate their grief into the redemptive work of peace, the children would find themselves-wittingly or unwittingly — entangled in all of these registers.

In the first section of this article I historicise Osada's decision to solicit Hiroshima survivors' narratives towards the goal of peace. Movements encouraging non-intellectuals, and particularly children, to engage in personal narration first emerged in Japan in the 1920s and 30s, with the initial aim of helping to develop character and articulate social problems. In this regard, Children of the $A$-Bomb was part of a longer tradition, instrumentalised for the needs of postwar Japan. In the second section I examine young people's navigation through this personal and political work in Children of the A-Bomb. The children's testimonies, I note, flex across scales, relating intimate personal experiences to larger themes about their city, their country, and humanity itself. But the work of peace was imperfect, and some of the children communicate their ambivalence or even distrust towards the popular pacifist vision that Hiroshima's and Japan's leaders embraced in the late 1940s and early 1950s.

In the third section I pick up the more explicit politics that the children's stories came to represent. The book was the basis for two Japanese films, both of which were caught up in anti-nuclear, and even anti-American positions, and neither of which fully achieved the goal of communicating both the deplorable intensity of war and the spiritual imperative of peace to a broader audience. This section also examines the book's mixed reception in the United States, arguing that while some critics used Children of the A-Bomb to confirm the dangers of nuclear weaponry, they found it difficult to find specific points of intellectual engagement with the unfamiliar genre of juvenile writing.

The concluding section returns to consider the text's ambivalent place in the longer tradition of Japanese life writing. It focuses in particular on the figure of the unwilling writer, or the writer whose capacity for expression fails in the face of the intensity of their experience. In the depths and rawness of their grief, the children's stories transcend the more pragmatic projects of remaking Japan and Hiroshima, as well as the global and local politics of the anti-nuclear and peace movements. These young people were asked to do the work of peace, but their writing also testified to a pain that defied articulation altogether, and to a need for resolution that was ultimately beyond their ability or responsibility to deliver.

Children of the A-Bomb offers a powerful addition to our understanding of juvenile writing. Whether writing for intimate audiences in the context of diaries or family 


\section{JJS December (202I) Special Issue: Juvenilia, Trauma, and Intersectionality}

magazines, finding solace and stimulation in their retreat into paracosms and play, or rehearsing for the serious work of adult writing, young authors are usually intensely motivated and teeming with creative force, and they write for personal satisfaction, exploration, relief, or, in some cases, praise (e.g., Alexander and McMaster; Robertson). But Children of the A-Bomb was not clearly a site of artistic, emotional, or intellectual fulfillment for all of its writers. What it does evince are examples of incomplete or ambivalent catharsis, pleas for a deliverance that could not be assured. The contributors were members of the bibakusha, the Japanese word that literally means "bomb-affected people," who faced not only the horror of a nuclear attack, but also the responsibility of carrying on with life, enduring loneliness, frightening medical conditions, and often painful stigma (Yoneyama 88-89). They saw their own experiences mirrored in their destroyed city and in its strange rebuilding, creating an eerie geography of grief that was increasingly out of sync with their feelings. And though many of the young authors told their stories with compelling beauty and intensity, using the project of life writing to strengthen personal character and collective citizenship, their works also heave with unresolved anguish. At least some of the accounts suggest that the children were encouraged to put whatever hopes they still maintained into a prescribed political project, or a desperate moral vision that even their best, most sacrificial writing could not be sure to deliver.

Children of the A-Bomb also, importantly, deepens our understanding of trauma in juvenilia (e.g., Alexander), as well as the recent "emotional turn" in the history of childhood (e.g., Olsen). The children draft testaments to human survival, pleas for peace, and expressions of grief and even cynicism at humanity's vile achievements. But this is impossibly grave work, and, as I indicate in the final section of this paper, the young authors are all too often rendered silent by the inexpressibility of their pain. Cathy Caruth notes how the force of a traumatic experience "would appear to arise precisely ... in the collapse of its understanding" (Introduction 7). Traumatic experiences are out of reach; they beggar articulation and defy comprehension. "The traumatized, we might say, carry an impossible history within them, or they become themselves the symptom of a history that they cannot entirely possess," Caruth explains (Introduction 5). The young writers of Children of the A-Bomb were pressed into different forms of political service by a nation in the process of remaking itself, and a community of anti-nuclear advocates that needed their testimonies to plead its case. Above all, they were asked to make their sacrifice and their suffering worthwhile by reliving it, documenting it, and giving it meaning as a call for peace. But this was a task that could never fully express, let alone honour, their sorrow and hurt and rage. Through Children of the A-Bomb, juvenilia studies can recognise children's writing as a site of traumatic memory, a tool for political action, and also a fundamentally limited form of communication that could only know the surface of human pain, and leave readers wondering at the unsounded depths below. 
Lieffers | Juvenilia, Hiroshima, and the Politics of Peace

I.

After the Second World War, Japanese society underwent a fundamental transformation. As historian John Dower explains, "Defeat, victimization, an overwhelming sense of powerlessness in the face of undreamed-of weapons of destruction soon coalesced to become the basis of a new kind of anti-military nationalism" (493). The country's new constitution of 1947 explicitly emphasised the nation's commitment to peace, and when Osada began his project, Hiroshima was experiencing a kind of engineered renaissance. As early as September 1945, the governor indicated his plans to rebuild the city as "a major inner sea tourist point," and he called for funding to create "a peace memorial city" (qtd. in Zwigenberg, Hiroshima 28). The horrors of war would be remade into a politics of peace, signifying postwar recovery and a forward-looking mentality of which the occupying Allied Forces thoroughly approved (Yoneyama 19-20). In 1949, civic leaders passed legislation that would officially designate Hiroshima "a peace memorial city symbolizing the human ideal of the sincere pursuit of genuine and lasting peace" (Hiroshima for Global Peace 12). They constructed a park, museum, and memorial hall dedicated to peace, and they even held a yearly Peace Festival on the anniversary of the bombing (Hiroshima for Global Peace 13, 20).

This renewed purpose was an important outlet for many bibakusha (Yoneyama 105), but it also created a narrow range of acceptable scripts for how they might react to the tragedy. The task of making peace had papered over the lasting health conditions, discrimination, and economic struggle that many bibakusha faced in the late 1940s and early 1950s. Neither the United States occupying force, nor the Japanese government, provided any special welfare or medical care for their support, while censorship limited the circulation and publication of some key medical information about the effects of radiation sickness (Shibata 50). Indeed, Ran Zwigenberg notes that the commemoration of Hiroshima was not generally cast "in terms of grief and loss," but rather emphasised "transformation, rebirth and, ultimately, progress" (Hiroshima 24).

Like the city of Hiroshima, Arata Osada was experiencing his own rededication to the cause of peace. The events of August 1945 had nearly killed him. He had been wounded by shards of glass from the explosion, paired with radiation sickness, and he later wrote that "for four months I roamed in the land of Death before some fate gave me back my life" (Bajo; Osada, "Appendix II"; Dust Jacket). After his recovery, he committed the rest of his life to the promotion of children's welfare, as well as education for peace. The "renunciation of war is a duty ... that the Japanese people owe to the whole human race," he wrote, noting that the "realization of this shall depend fundamentally on the power of education" (Preface xxiii and xxv).

Children of the A-Bomb was meant to be a key piece of this education, and it followed from a longer Japanese history of purposeful life writing. Historians have noted the survival of numerous private diaries by young writers, as well as education professionals' promotion of composition and diary writing in the classroom, dating 


\section{JJS December (202I) Special Issue: Juvenilia, Trauma, and Intersectionality}

back to the Meiji period (Cave and Moore 294). The 1920s and 30s in particular witnessed a new movement for self-narration, aimed especially at working-class children. Seikatsu tsuzurikata ("ordinary life writing") was a reaction to the strict bureaucratic control of Japanese elementary education. Taking advantage of relative laxity in the composition curriculum, teachers encouraged students to write honestly about their daily lives. This was not simply a form of writing education; it was also a way for children to develop strength of character, as well as an awareness of social issues. "It is," as some of its first proponents explained, "for accurately observing the actual problems in society and the situations of children's everyday lives, understand[ing] the principles existing and working in daily life, and teach[ing] children to understand them" (Tadayoshi Sasaoka et al., qtd. in Hiraoka 25). Indeed, this was a largely left-wing effort; "existing," as Gerald Figal notes, "as an idea more than as a widespread practice, its aim was toward the development of a proletarian voice and class consciousness" (907).

While some magazines published children's compositions in this early period (Hiraoka 25), the popular writing movement would expand significantly after the war. Mainstream publications featuring personal writing by common people flourished in the late 1940s and 1950s. Harukanaru sanga-ni ("In the Faraway Mountains and Rivers," 1947) and Kike wadatsumi no koe ("Listen to the Voices of the Sea," 1949), for example, were collections of writings by university students who had died during the war; the books had strong anti-war messages, and the latter was made into a film. Petra Buchholz also notes that the intellectual magazine Sekai ("World") invited readers to submit accounts of the day of surrender (15 August 1945), while conservative and women's magazines collected and published personal accounts by war widows in the 1950s. Around 1960, regional papers also began to solicit contributions from soldiers (202). From the late 1950s, grass-roots writing groups would develop into a broader fudangi ("everyday writing") movement (Figal 907), exemplifying a quest for self-expression that is also present in the more individualised jibunshi ("self-history") movement; popular to this day, jibunshi encourages selfpublishing of personal histories (Figal; Buchholz).

Although it had diverse supporters, much of this postwar popular writing movement was tied, either explicitly or implicitly, to progressive politics. As Adam Bronson notes, some progressive postwar educators, following their precursors in the 1920 s and 30s, encouraged students to write in unadorned language about authentic life in their local communities, particularly as part of their social studies education (128). The left-leaning Institute for the Science of Thought, moreover, sought to promote egalitarian, pluralistic democracy by recognising the philosophical and political significance of ordinary people's observations. This work dovetailed with the larger Japanese "circle movement" in the early 1950s, which encouraged membership in various voluntary associations. Many of these circles focused on producing critical documentary accounts of everyday life that were then distributed and discussed, with the hope that citizens might connect local problems to larger class or national issues. 
"Observers of the movement," writes Bronson, "believed that this cycle of observing, writing, and discussing might produce citizens capable of realizing the promise of postwar democracy" (Bronson 124; Hiraoka 22).

Young people's writing was particularly valued through this period. Some circles committed to studying books such as Muchaku Seikyō's 1951 bestseller Yamabiko Gakkō ("Echo School"), an edited collection of writings by rural middle-schoolers that was made into a film the following year (Bronson 123). Through such texts, notes Bronson, "adolescent students were empowered to become teachers, educating adult readers about how poverty affected their daily lives and inspiring them with their determination to overcome it against seemingly hopeless odds" (130). Other books of the period similarly compiled young people's thoughts on everything from local elections to their experiences with US troops; the latter was an initiative by the Japanese Association for the Protection of Children, an organisation that elected Osada its first president in 1952 (Centeno Martin 3, Frühstück 157). Osada's decision to gather accounts from juvenile survivors of the Hiroshima bombing was thus intimately connected to a much larger trend of soliciting and employing children's writing for both individual and collective learning. The narratives were believed to have the potential not only to develop the juvenile authors' own strength and character, but also to promote awareness of the horrors of the bomb and nurture a culture of democracy and peace.

Indeed, Osada's prefatory material for Children of the A-Bomb cast the children's writing as a matter of purity and truth, appealing to the romantic notion that young people provided access to a shared, inherent human essence:

For this publication, I made up my mind to collect and classify the accounts written by boys and girls whose thought, at the time they underwent that tragic experience, had not yet been tinted with any specific political ideology or view of the world. It is my hope that these accounts will forever serve as material for "instruction" in the ways of peace, so important for the "education" of the world, and as reference material for studies in the cultural history of the human race. (Preface xx)

The first English-language book jacket similarly claimed that "the youngest witness would be the most impartial," and it added that "of all the literature on the subject of the A-bomb, this is the least propaganda-ridden. The children have no axe to grind. They have simply told their stories." Though the book was clearly engaged in a movement of public awareness and a campaign against nuclear weapons, using children's stories to back these aims seemed to place them a transcendent, apolitical, and universal moral register. Ordinary children's writing about extraordinary experiences could impart powerful lessons. 


\section{JJS December (202I) Special Issue: Juvenilia, Trauma, and Intersectionality}

\section{II.}

CHILDREN of the $A$-Bomb is notable for its candour: though certainly not as impartial as Osada would claim, the book's young authors bluntly narrate their own experiences of the bombing as well as their difficulties in reconciling them with Japan's contemporary political environment. Many offer intense sensory descriptions that make the experience of atomic warfare intimately horrifying. For instance, Junior college student Naoko Masuoka recalled, "My hands are burned black, and a yellow liquid is dropping like sweat from the broken skin. There is a queer smell. Suddenly my tears come" (301). Vivid attention to colour and graphic similes helped express the inexpressible. One adolescent said his sister's face resembled a "burst-open pomegranate" (364); the sounds of people calling for help but necessarily ignored were also a common refrain. "Those voices ... they aren't cries, they are moans that penetrate to the marrow of your bones and make your hair stand on end" (273), wrote Hisayo Yaguchi, an eleventh-grade girl who was in fifth grade at the time of the bombing.

For other children, such as eleventh-grader Iwao Nakamura, the experience could be offered only as a series of terrifying images:

The child making a suffering, groaning sound, his burned face swollen up balloon-like and jerking as he wanders among the fires. The old man, the skin of his face and body peeling off like a potato skin, mumbling prayers while he flees with faltering steps. Another man pressing with both his hands the wound from which blood is steadily dripping, rushing around as though he had gone mad and calling the names of his wife and child—ah-my hair seems to stand on end just to remember. This is the way war really looks. (234)

Some also expressed a sense of detachment from their reality: "It can't be possible that I-.' I looked at my two hands and found them covered with blood, and from my arms something that looked like rags was hanging and inside I could see the healthy-looking flesh with its mingled colors of white, red and black" (353-4). At a distance from her own trauma, the writer, Atsuko Tsujioka, put her reader in the same position of helpless witnessing. "I could feel my face gradually swelling up," she continued, "but there was nothing I could do about it" (354).

The horror of a young person's own trauma and wounds could be amplified by those of the people around them. Several young writers reported needing medical treatment, but hospitals were overflowing and filled with cases even more frightening than their own $(13,106)$. Fifth-grade writer Ikuko Wakasa described a man who was terribly burned: "his whole body turned the color of dirt and got soft" (15). Years later, she worried about what poison lurked inside her. "Still people are dying in a way that reminds us of that day," she wrote. "When I only hear about the suffering of 


\section{Lieffers | Juvenilia, Hiroshima, and the Politics of Peace}

people who have that radiation sickness, it makes me so frightened that I wish I could think of some way to forget about it" (16). Children did not experience trauma and injury alone, but rather as mirrored by those around them, intensifying their sense of the wounds that they had already received — or barely escaped — and freighting them with fears about damage yet to come. Atomic trauma was not momentary; among its greatest horrors was its capacity to linger in the body and haunt the future self.

Indeed, many saw the morning of August 6 as a dividing moment in their lives. The bomb seemed to shatter time, to create infinite, simultaneous instances of change: "I don't know whether the unearthly silence was first, or the flash. All I can say is that in some ten-thousandths of a second, an unimaginably great number of events took place," wrote college student Mitsukuni Akiyama (414). These events separated children not only from loved ones, but also from their own identities. "Too much sorrow makes me like a stranger to myself' (227), wrote tenth-grader Masayuki Hayashide. Another spoke of being emptied out by the experience. "This Mieko of the present, who has no dream or anything else, in the past was brought up quietly, wrapped in the warm love of her two parents. In this present Mieko there is not a single trace of the former Mieko" (322). Mieko Hara was not the only young person to feel separated from herself by the scale of her grief and loss. Coming back to a rebuilt Hiroshima, the gleaming city of peace, was an uncanny experience for some. "Every word we hear, every object we see, lacking any connection with the past, makes us feel only 'surprise," wrote Yaguchi, adding that "change which transcends such alteration due to time gives me only a strong feeling of incomprehensible surprise" (280-81). This experience of seeing a city rebuilt and memories covered over was nothing to celebrate; rather, it was an unsettling loss of some external confirmation of the personal destruction they had known, and a reminder of how much more difficult the process of personal rebuilding would be.

Caught between the statuses of victim and survivor, and forced to keep pace with a rebuilding nation, the young writers commonly experienced feelings of guilt, distress, and meaninglessness, coupled with stigma and teasing about their injuries. "I got so I couldn't stand my own existence," wrote Yaguchi. "For a while I was troubled by the impulse to throw away my own body. I felt only the meanness of human beings, their weakness, and the distress of human life; and I could not find any pleasure in the fact of being alive. I am going to become a perverse, cynical personI was terribly afraid of that thought ... I was conscious of destruction on all sides" (281). Hibakusha, especially those bearing visible scars, were often ostracised for embodying the misery of the past, as well as unknown health dangers, but some writers took solace in a sense of shared purpose. Though Setsuko Yamamoto was teased for her twisted finger, whenever she saw others with similar scars, "I have a feeling," she wrote, "that I would like to run up to them so we could comfort and encourage each other. I believe that this is a common spirit among all the survivors. Those of us who have actually experienced with our bodies the fact that war is a 


\section{JJS December (202I) Special Issue: Juvenilia, Trauma, and Intersectionality}

frightful and wretched business - we earnestly wish to do everything in our power to be friendly with all the people of the world and to make peace last forever" (126).

Like Yamamoto, many young writers were all too aware that they had a job to do. During the war, they had been asked to be icons of patriotism, and many had served as labourers; after the war, as Sabine Frühstück has argued, children were "assigned the task of creating peace" (164). For some, this was personal work, and the students articulated how they strove to develop the right kind of character: they planned to help others, or to focus on their studies and cultivate their minds to honour the dead. Setsuko Sakamoto, a junior college student, wrote that she must "keep my own spirit sternly calm so that I will be able to live worthily on behalf of my forty friends [who died in the bombing]" (307).

Others made sense of their improbable, even reluctant resilience by looking to the city's natural life, which offered a kind of allegory for their own and their nation's rebirth and healing. "A willow tree was already sending out new leaves above a corpse that was without ears, eyes, nose, mouth etc.," wrote ninth-grader Toyozo Kubota. "This was like a picture that went beyond words in symbolizing the image of Hiroshima rising out of the desolation and pressing forward" (203). Eleventh-grader Hiromi Sakaguchi also admired the dauntless persistence of the weeds that sprang up in the blackened wasteland. Sakaguchi saw meaning, too, in the waterways that defined the city's famously beautiful geography:

Hiroshima was not vanquished. Always the clear water of the Ohta River flows through its seven channels. That pure, limpid water was very beautiful.

I wanted to become that water.

If you ask why, it is because that water knows neither pain nor sorrow. The clear stream of the Ohta River washed away the suffering from my spirit. (255)

Some even extrapolated these personal lessons of resilience to humanity as a whole. As Yaguchi wrote, "Falling down, we rise to our feet; again falling we rise again - the path which humanity follows is a thorny mountain path. Even though we stumble, we may not lie there where we fall. Eventually a beautiful pure spring will appear before our eyes. We must keep on walking until we are able to scoop up the clear spring water with our own hands. That is what it means to live" (281). Though there were common themes, there was no single way to be a bibakusha, and narratives of survival and peace took complex forms.

The students were also keenly aware that peace was political work. Some clearly explained the shortcomings of their previous identity, fostered in militarism: "The prayer that we had prayed, 'For Victory's Sake, For Victory's Sake,' had led straight to the path to Hell," wrote one student (342). Now, they would transmute their experience as bibakusha into a unifying, redemptive call. The younger authors 


\section{Lieffers | Juvenilia, Hiroshima, and the Politics of Peace}

articulated the goal of "peace" most explicitly and repetitively, drawing a direct line from their own pain to this new national narrative. "When I remember how my brother suffered and died like that my heart overflows and I can't stop crying," wrote sixth-grader Taeko Matsumoto. "At the same time I think that there must never be another war. I pray that all the countries of the world will become bright with peace" (85). "Just as I am growing up," wrote another, "Hiroshima is growing up to become the City of Peace" (56). She witnessed a kind of geography of healing in the parallel between her own growth and the city's rebirth, and other children explicitly described helping with rebuilding projects. Evidently aware of their country's new positioning, many young writers worked outward from their own experiences to their city and nation, humankind, and the overarching goal of peace, moving from the intimate to the transcendent.

The peace movement, to be sure, was an important coping mechanism for many. A survey of survivors in 2005 showed that many continued to emphasise the importance of peace, and a number indicated that it helped alleviate trauma (Hiroshima for Global Peace 22-23). But in the immediate aftermath of the conflict, some found this shift to peace to be too simple, even distasteful. Mitsukuni Akiyama, a twelfth-grade boy, could not escape the memories etched on his body: "When I look at the ugly scars from my own burns, the faces of those people appear and fade and appear, and in spite of myself tears are drawn from my eyes. It must not happen a second time .... God taught us how to 'forget.' But can I 'forget' that instant, that spectacle?" (417) His wounds were associated with deep grief and trauma whose meanings could not be easily reworked into some new politic.

Taking umbrage with his city's eagerness to move on, twelfth-grader Tohru Hara was more scathing:

Can we say that true peace has visited Hiroshima?

The "Peace Movement" that traded on the three hundred thousand victims of the A-bomb, and the "Peace Fair," and the goings-on of the August sixth "Peace Festival." Who exactly is it who is doing all this? Were you in Hiroshima on that sixth of August?

If things continue like this, there will certainly be no way to answer those who say that the name "Hiroshima, the City of Peace" is nothing more than a trade name to make outsiders spend their money here. Is it all right if Hiroshima, the City of Peace, in [sic] just another tourist resort? It is right that those pathetic human beings covered with keloid scars should be exhibits in a show booth? Or that they should be guinea pigs in a laboratory? You excursionists who visit the Peace Dome on the bank of the Motoyasu River! That is not a side-show you are looking at! (378-79) 


\section{JJS December (202I) Special Issue: Juvenilia, Trauma, and Intersectionality}

Another student, Sumie Kuramoto, similarly dwelt on the terrible irony of the Peace Festival: "I couldn't possibly work up a festive spirit, and I spent that day in smouldering discontent. I saw with amazement how many people have such frivolous minds that they can find pleasure in any little thing so long as someone else pays for it, with no concern at all for how much the victims sorrowed, no understanding of the blows they had suffered" (397).

Hiroshima, indeed, had moved on quickly. As early as 1947, the city's Tourist Promotion Section even went so far as to note that "Hiroshima enjoys a great location on the inland sea, with beautiful nature and ski resorts close by." Immediately after this lighthearted image of recreation, it added that "Hiroshima was made famous internationally by the atomic bomb, and we can make it a world-famous tourist city for both domestic and foreign visitors" (Zwigenberg, "Hiroshima Castle" 204-05). The same year as the publication of Children of the A-Bomb, Hiroshima hosted the Sixth National Youth Athletic Competition, inviting students from across Japan. A brochure from the event proclaimed the city as "Castle city Hiroshima! Military capital Hiroshima! Atom Hiroshima! Hiroshima, which was built as a peace city through an unprecedented special law" (Zwigenberg, "Hiroshima Castle" 207).

Without adequate medical care or compensation for their injuries, the rhetoric of peace was cold comfort to some hibakusha, and many noted, with varying degrees of directness, their poor treatment and continued suffering, challenging the narrative of progress and rebirth. Fifth-grader Hiroko Harado described her mother being examined by "Occupation Army" but never getting any real medical care (45), likely a reference to the observation-only policies of the Atomic Bomb Casualty Commission. Lingering radiation disease, combined with serious financial stress, was also a theme in many children's narratives, while a few even noted an epidemic of suicides (e.g., 21). "There are people somewhere who say that these victims were the price paid for the Cause of Peace," wrote Tohru Hara. "But has anything come back to us which is worthy of such a costly sacrifice? Is it not true that while we ask for a real peace, this thing that has been handed out to us is after all nothing but a counterfeit of peace?" (379). Others appreciated the benefits but were troubled by the terrible cost. "Why could we not have won Democracy by some other method which would not have necessitated this most cruel sacrifice of Hiroshima?" wrote Yasuko Moritaki. "In order to achieve this Democracy, which has as one of its chief objects the perfection of this precious dignity of the individual, was it necessary to slaughter these priceless 'individuals,' and moreover, two hundred forty-seven thousand of them in one instant? This great contradiction troubles my mind painfully" (285). Even an honest peace, beyond Hiroshima's seemingly vulgar rebranding, might not be enough to redeem their pain.

Some students confessed a desire for revenge and expressed their bitterness, despair, and resentment at Japan's surrender. Kuramoto explained, "It is not that I like war in the slightest, but I felt that it was unpardonable toward the young heroes who had fallen so valiantly, so beautifully, so manfully" (390-1). Japanese soldiers, 


\section{Lieffers | Juvenilia, Hiroshima, and the Politics of Peace}

she added, had helped struggling victims, while the American planes seemed only "hateful and inhuman!" (388). While modern-day jibunshi accounts of 15 August, the day of surrender, generally include a reflective element that interrogates this wartime attitude (Buchholz 209), many of Osada's young writers had little such sense of closure. The Japanese sacrifice, in fact, seemed all the more bitter and futile because it had not brought the much-promised peace: the students knew they were supposed to give some kind of meaning to their pain, but as the Korean war raged nearby and their islands hosted American troops, they could not control the actions of other nations. Their anguish had seemingly been for nought.

Many young writers, in fact, were deeply ambivalent about the possibility of achieving any sort of spiritual insight or nuclear universalism. "Does this kind of event mean you can only pray to God?" wrote one. "No, it would rather be nearer the truth to say that the feeling of wanting to pray to God was not even aroused. In the figure of this mother [holding the hand of her dying child], as uneasy as if she were haunted by something and quite at a loss to know what to do, there was little room to discover any such reverence" (428). For others, faith in humanity or any transcendent good had been broken by the moral tragedy of atomic violence. Science had clearly outpaced humanity, and they feared there was little likelihood of catching up. "In the left hand, penicillin and streptomycin - in the right hand, atom bombs and hydrogen bombs," commented Yoshiko Uchimura. "Now of all times the peoples of the world ought to reflect coolly on this contradiction" (352). Others questioned even the concepts of good and evil, and pondered their relativism: "I wonder what the feelings of General Tojo were as he died miserably. From the depths of my heart I regretted Mr. Tojo's death. Are dictators good people or bad people? Are black-marketeers good people or bad people? That is just a convenient measuring stick that human beings have made" (399).

The bibakusha had been asked to sublimate their pain into peace, to find redemption in their unwilling sacrifice. As many intellectuals predicted, the life writing movement offered up profound philosophy, but it was also a philosophy that challenged any simplistic narratives. Osada's compilation left room for a complex vision of peace that was able to honour the ambivalence and rawness of individual, subjective experience, an important aspect of the life writing movement from its inception. The children saw themselves in the resurrected Hiroshima, but they also questioned the superficiality of the city's new emphasis on peace. They testified to human resilience, but also to lasting pain. They worked for the good of humanity, but they did not always trust in it, nor did they find that their messages were universally well received. 


\section{JJS December (202I) Special Issue: Juvenilia, Trauma, and Intersectionality}

\section{III.}

$W_{\text {HILE much Japanese life writing remained private or was shared only in local }}$ circles, Osada's decision to publish Children of the A-Bomb explicitly drew the students and their sentiments into larger, public arenas of peace education, as well as an emerging global anti-nuclear movement. This was done, arguably, without their full consent. One sixth-grade student, Junya Kojima, for example, did not even know that his essay had been published in the collection until the 1990s, though he was aware of its appearance in Sekai in the summer of 1951 (Namba). Participation in antinuclear politics, moreover, was not uncontroversial, even in Japan: the movement had strong anti-American and leftist overtones, and though the occupation was slated to end in 1952, there was still substantial concern about antagonising the United States with explicit critiques of American policy or the decision to drop the bomb in the first place. In his accompanying material, however, Osada amplified many young authors' observations that there had been no real warning of the attack, which ensured maximum damage to civilians. He also contended that the bomb was not necessary for Japan's surrender, and he made specific statements against nuclear proliferation and the possible use of nuclear weapons in Korea (Preface xxix and xxx). With regard to censorship or retaliation, Osada's son, Goro, remarked that "fortunately, nothing happened, maybe because the essays were written by children, not adults" (Bajo). Yet as the messages in Cbildren of the A-Bomb moved into broader circulation in Japanese anti-nuclear activism and film, and even beyond Japan itself, the children's complex experiences and philosophies were often flattened, sentimentalised, or simply misunderstood. The nuances of children's life writing and their struggles to cope with atomic traumas translated sometimes awkwardly into the ideologically charged work of anti-nuclear activism and its opponents.

Children of the A-Bomb was a launching point for numerous different strands of public engagement. In the Kansai Region, for example, students from Osaka University spearheaded a movement called "In Response to Children of the Atomic Bomb," and Osada also compiled and published a collection of responses in 1953, demonstrating that life writing could form a foundation for reflective discussion and thoughtful citizenship (Namba). Many of the children were also invited to join an organisation called Friends of the Children of the Atomic Bomb in 1952-53. Sometimes also called the Fraternity of Children of the A-Bomb, the group arranged for hibakusha to travel around Japan to present lectures and plays for the purpose of promoting peace and condemning nuclear weapons. While at least one member, Yuriko Hayashi, spoke positively of the sense of comfort that came from this community, this feeling was not shared by all of Osada's young writers. "Under the direction of adults," the organisation's vice-president Masaaki (Toshihiko) Tanabe later explained, "the innocent activities of children gradually took on a political tinge. Because of my activities, I couldn't get a recommendation for admission to high school, and I realized I was once again going to suffer on account of the atomic 


\section{Lieffers | Juvenilia, Hiroshima, and the Politics of Peace}

bombing" ("Translations of "Children"). He did not participate in the peace movement again for some six decades.

As with many other examples of popular life writing in this period, Children of the A-Bomb was also immediately identified as a good candidate for adaptation into film. The left-leaning Nihon Kyöshokuin Kumiai, for example, Japan's largest teachers' union, wanted to ensure that the book's stories and message were widely known, and they commissioned a film adaptation, Children of Hiroshima (Genbaku no ko), directed by Kaneto Shindō. Released in 1952, the movie was based only very loosely on the accounts in Children of the $A$-Bomb. The plot follows a gentle, compassionate young teacher who returns to Hiroshima several years after the bombing. As she moves through the city, she meets many of her former students as well as other survivors, and the audience witnesses their struggles with health problems, lost family members, and social and economic disruption.

Though Japan's foreign ministry, fearing diplomatic consequences, reportedly tried to discourage any awards for the film, it was screened at Cannes in 1953 ("Hiroshima ... A-bomb Films"). But Children of Hiroshima in fact addressed very little of the bomb's horror head-on. The young writers' graphic descriptions of death and destruction were reduced to a brief montage of withering plants, flames, and blood dripping down women's naked bodies. This mild approach is clear from a review in the British Monthly Film Bulletin, which described the film as moving and sympathetic, and praised it for a narrative "surprisingly free from recrimination and bitterness; there is, instead, a kind of baffled anger and regret that the events of ten years ago should, even now, cast a shadow of death over the lives of the Japanese people" (J. G. 69).

Perhaps unsurprisingly, the Union reportedly dismissed the film as a "tearjerker" without any real "political orientation" (quoted in Lowenstein 84). Insistent on demonstrating the atrocity of the bomb and the urgent need for a non-nuclear world, they commissioned director Hideo Sekigawa to make a second, more explicit film, which was simply titled Hiroshima (1953). If Children of Hiroshima "relies on a discourse of healing and forgetfulness," as scholar Bianca Briciu has argued, "Hiroshima creates a visceral type of peace education through vicarious traumatic inscription of bodily pain on the bodies of spectators." This second film was indeed much more ambitious in scope. It addressed issues of stigma, the lack of government support, and the health consequences of the bomb, and it also did not shy away from searing depictions of the destruction of the attack. Filming started on location around Hiroshima in May 1953, and some 88,500 locals, including some of the contributors to Children of the $A$ Bomb, participated as extras in the movie's most astounding scenes of destruction. Hayashi, an extra in the film, described how they "smeared a mixture of mud and ink on our faces and went into the river. I remember having a vivid flashback of that day" ("Hiroshima ... A-bomb Films").

But Hiroshima, too, would face critics. It is a testament to the exceptional boldness and candour of Osada's young writers that almost as soon as the second 


\section{JJS December (202I) Special Issue: Juvenilia, Trauma, and Intersectionality}

film was completed, Japanese authorities were concerned that it was too antiAmerican ("Hiroshima ... A-bomb Films"), and possibly too communist. Yuko Shibata notes that aside from its graphic horror, the film is also notable for its explicit denunciation of the atomic bombing and its leftist orientation. The latter was made clear through the use of a phrase from an earlier Charlie Chaplin film, Monsieur Verdoux (1947): "One murder makes a villain, millions a hero." It was no accident, Shibata argues, that the filmmakers chose to quote Chaplin, who was demonised in the American Red Scare and by 1952 was living in Europe in exile (47). As a consequence of this positioning, and probably bowing to political pressure, the original distribution company reneged on their agreement to release the film in August 1953 (Broderick and Hatori 79). The Teachers' Union distributed the film instead, but the Ministry of Education, Science, Sports, and Culture would not allow it to be shown in schools (Broderick and Hatori 80). Aside from an additional, limited showing in the United States in the mid-1950s, the film was all but forgotten for decades. The experiences of the atomic bomb's young survivors would remain most influential in their original form, as films could not readily convey these complex stories of victimhood, survival, and peace in a politically charged post-war Japan.

As Children of the A-Bomb travelled to the English-speaking world, a handful of critics urged serious reading. British philosopher Bertrand Russell's assessment appeared on the dust jacket of the 1963 American edition, and he was unabashedly political, condemning "those countries which decreed or applauded the destruction of Hiroshima," and singling out Harry Truman for his lack of guilt over the decision to drop the bomb. Nuclear armament and the pursuit of peace, he argued, were fundamentally incompatible, and he commended Children of the A-Bomb "because it may stimulate sluggish imaginations and turn men away from the pursuit of death and torture to the hope of a happier and peaceful world." But Russell engaged little with the intellectual content of the young writers' reflections, instead employing a broad understanding of their experiences to advance a specific political commentary.

Other reviewers were more sensitive in their philosophising. Psychiatrist Robert J. Lifton, writing in the New York Review of Books in 1963, grasped the crux of the work that Children of the A-Bomb's young writers were being asked to do:

The question of how much the people of Hiroshima themselves should serve as living symbols is perplexing to them and to the city administration as well. To what extent should they leave the experience behind and permit themselves to look ahead, or away? To what extent should they serve as a symbol of death? There is no precedent for how a person or a city victimized by an atomic bomb should behave.

Perhaps we should not be surprised that the children of Hiroshima, in this remarkable collection of compositions, have been called upon to solve this dilemma. 
As a universal symbol of purity, children, he pointed out, were an important reminder of essential humanity before the barbarism of adult conditioning. But this same innocence meant that children were all too often asked to do "our historical dirty work," whether assimilating to a dominant culture or "wheeling them in baby carriages at the head of ban-the-bomb parades." This was an unresolved tension in Children of the A-Bomb, but Lifton believed it did not preclude the collection's value as a unique testament to the unique experience of atomic warfare. "The book is an extraordinary document," he concluded, "and however its readers may try to fend it off, something is bound to get through. And this might be of great help to us."

Though Lifton, unlike Russell, quoted extensively from the children, his review was more interested in understanding the process of recovery than amplifying the call for peace. The power and intimacy of the children's voices and their message in fact seems to have made little impact on Western thinking about atomic weaponry. A handful of references to and extracts from the book appeared in publications such as Scientist and Citizen, which was implicitly anti-nuclear (Brewer 187), and, later, the antiVietnam War Bulletin of Concerned Asian Scholars (e.g., Satoh 28), but these were rare.

In his study of the centrality of children in American understandings of the bomb, Robert Jacobs argues that whether "as data points, as celebrity victims, or as martyrs, the children of Hiroshima were a screen on which Americans projected their own relations to the weapons" (270). But at their most generous, these philosophical reflections were often brief, a superficial form of nuclear universalism that only gestured to transcendent messages of peace and humanity and did little to understand the children as individuals or as writers, or to appreciate their various ways of engaging with, articulating, and even challenging the broader rhetorics of peace in which they were enmeshed. Most significantly, these meditations could never match the unknowable intensity and subtlety of the experiences of the bibakusha.

\section{IV.}

IN HER work on Japanese people's personal accounts of the surrender on 15 August 1945, Petra Buchholz notes that to "remember and to write down personal memories of the self taking part in history means simultaneously to be a member of a community who shared the same fate" (201). These narratives, she argues, cultivate a sense of belonging and generate a feeling of historical consciousness, a conceptualisation of one's own place in history, and a valuable, shared understanding of the end of the war as a time of new beginning.

Children of the A-Bomb, too, created meaning and community; the "Oleander Club," for example, is a group for the now-elderly writers who contributed to the collection. Some of their adult reflections were also featured in a new collection entitled Children of the Atomic Bomb: Since Then, published in 1999 (Namba). But despite 


\section{JJS December (202I) Special Issue: Juvenilia, Trauma, and Intersectionality}

its lasting impact and significance, Children of the $A$-Bomb is perhaps most haunted by what it cannot say, the moments when the young writers' words are inadequate, or simply run into silence, to the edge of human expression. "It is utterly impossible for me to record completely with pen and paper the tragic consequences that were due to that most inhumane A-bomb," wrote twelfth-grader Osamu Kataoka (401). It was emotional intensity that stopped the student cold. "I cannot bear to recall more than this of the scenes that I saw at that time," Kataoka explained. "They were simply too tragic. It was too cruel a business" (411). Some children elected to leave out details that were too raw to utter. "I was told various things about my father," wrote Mieko Hara. "These also I do not want to write down on paper ..." (323).

Scholars of childhood have often struggled to know the walled-up inner lives of young people, whose experiences are so often mediated through the ideologies and assumptions of adults. Juvenilia, though sometimes imitative or performative, can offer a glimpse through the cracks in those walls. Yet in cases of intense trauma, even the most intimate and expressive juvenilia cannot articulate the depths of experience and emotion. Mieko Hara's prose simply dissolved into grief: "I hate war! I hate war! To think that my mother, who was so cheerful and energetic, should be crushed beneath that big house-! Oh! I don't want to talk about it, I don't want to write about it! The more time passes, the greater becomes my grief. ... Oh, it is cruel. I don't want to publish it to other people. I want to keep it concealed within this little heart" (324). Regarding her mother's last words, Hara could offer nothing: "I cannot write any further ..." (323).

Here, the context in which these young authors told their stories is worth further attention. This was not seikatsu tsuzurikata, ordinary life writing, which had a long history in Japanese classrooms. Nor did it emerge from the children's own desire to express themselves. Rather, these young people were asked to revisit the darkest moments of their lives, and while many may have believed that this work had value, it seems to have pushed at least some young writers to the limits of their emotional and spiritual capacity. One contributor, Masaaki (Toshihiko) Tanabe, recalled the context of Osada's request: "In Japanese class the teacher urged all of us to write an essay. I thought it was a homework assignment, so I wrote one. Ordinarily we used coarse writing paper, but that time we were given a sheet of nice manuscript paper, so I felt I had to write a proper essay" (Bajo). Fifth-grade girl Ikuko Wakasa similarly felt that she had to write. "Since I was assigned this for homework, and even though I don't want to do it, I am making myself remember that awful time" (12). Many did not hide the fact that the labour of peace was an intensely difficult one. "We stand in awe of touching this part of our minds," confessed Toshiko Ikeda. "If I once let my thoughts revert to that time, those brutal scenes would revolve more than ever before my eyes as vividly as if they were things of yesterday. This was too cruel a sacrifice to be called 'a stepping stone to peace.' Even I have the feeling that I would like to avoid staring too intently at that 6th of August" (308). But the young writers of Children of the $A$-Bomb were told to make meaning of their victimhood and survival, to find 


\section{Lieffers | Juvenilia, Hiroshima, and the Politics of Peace}

redemption for themselves and their nation by reopening their wounds. To read Children of the A-Bomb is thus not only to read children's writing, but also to bear a burden of responsibility. For some, the texts were produced under duress, and in the context of deep pain that they may never have wanted to experience, to recall, or to share.

Some pressed on, though, with the conviction that their work might serve some larger goal. In his preface, Osada quoted Kikuko Nagara, a ninth-grade girl: "Each time I began to write, recollections of the disaster rose up in my mind, one after another. It was a hard job for me to write them down; I faltered several times because the pain was so sharp, as if I had touched a hardly healed wound. I resolved to write this, however, hoping that what I wrote would be a tribute to my father, sister, uncle, many friends and hundreds of thousands of people, who lost their lives" (xxi). But for a few, it is unclear whether there was any sense of tribute, redemption, or meaning to be made in recalling their agony. Yasuhiro Ishibashi, a tenth-grade boy, ended his narrative abruptly: "Into my ears there seeped the voices of the groaning people, the noises of the buildings as they burned and fell, and the faint rolling hum of aeroplanes as they passed beyond the distant edge of the night sky" (244). There was no meditation, no philosophy, and no attempt to link his experience to the peace movement. This should not be surprising. In the larger history of the bibakusha, these narratives are remarkable for their existence at all. "Even after nearly half a century," writes Yoneyama, "no more than a small scattering of the over 370,000 survivors who witnessed the Hiroshima and Nagasaki nuclear atrocities have openly voiced their survival memories." Though breaking the silence has been increasingly understood as a courageous act in recent decades, she notes that "survivors themselves are constantly disheartened by the incommunicability of their experiences" (89).

At the core of traumatic narratives, writes Caruth, is "a kind of double telling, the oscillation between a crisis of death and the correlative crisis of life: between the story of the unbearable nature of an event and the story of the unbearable nature of its survival" (Unclaimed Experience 7). The children of Hiroshima were assigned the work of reliving and recounting their unbearable, incomprehensible experiences for untold audiences. They were instructed to trust in the power of their narrative to transform grief into a greater cause of pacifism, a postwar, atomic version of the belief that children's life writing could help identify and ultimately resolve social problems. This was juvenilia for a political end and for a transcendent moral hope; it was also juvenilia

of trauma, and juvenilia of silent depth. Osada claimed that the accounts recorded "the cry of the atom bomb-affected child" (Preface xxii). Like a cry, the expression could not fully communicate the complexity and need beneath. The interpretation and action would have to fall to the readers, who would inevitably fail to meet them. Audiences could never begin to comprehend, let alone fulfill, what was laid before them.

"How can I find the words to tell how the burned and festering people spent day after day moaning, how people without anyone to care for them, with maggots 


\section{JJS December (202I) Special Issue: Juvenilia, Trauma, and Intersectionality}

crawling all over their bodies, died muttering in delirium?" wrote ninth-grade student Masataka Asaeda. "These people must have died without knowing about the defeat, hating the war and loving peace" (146-47). By making themselves vulnerable, by sacrificing themselves a second time, they gave readers a chance, too, to hate war and to love peace. Regardless of how they approached their task, and regardless of the difficulties of their work's adaptation into film and the shortcomings of its reception in the nuclear-armed West, what these young writers did was surely enough. Osada's choice to include their halting storytelling, their confused feelings about surrender and good and evil, and even their scepticism of the politics of peace itself, testified to trauma's axes of experience. Children of the A-Bomb bears witness to the agony and wisdom that children could know, and from which readers might strive endlessly to learn.

\section{NoTES}

${ }^{1}$ While family names traditionally precede given names in Japanese, this article uses the given name-family name formulation that was employed in English-language editions of Children of the A-Bomb.

${ }^{2}$ All English-language translations, except those from the Preface, are taken from the 1959 edition of the book, translated by Jean Dan and Ruth Sieben-Morgen. The translations of the Preface are taken from the 1982 Harper Colophon edition.

\section{WORKS CITED}

Alexander, Christine. "In Search of the Authorial Self: Branwell Brontë's

Microcosmic World.” Journal of Juvenilia Studies, vol. 1, no. 1, 2018, pp. 3-20, doi: $10.29173 /$ jjs126.

Alexander, Christine, and Juliet McMaster, eds. The Child Writer from Austen to Woolf. Cambridge UP, 2005.

Bajo, Toshiko. "Translations of 'Children of the A-Bomb' Grow in Number."

Chugoku Shimbun, 20 November 2009, www.hiroshimapeacemedia.jp/?p=19934.

Braw, Monica. The Atomic Bomb Suppressed: American Censorship in Occupied Japan, 1945-1949. Liber Förlag, 1986.

Brewer, Tom. "Nuclear Job Unfinished?" S/C Exchange, Scientist and Citizen, vol. 9, no. 8, 1967, pp. 1887, doi: 10.1080/21551278.1967.10114783.

Briciu, Bianca. "Peace Lessons: Melodramatic, Visceral and Moral Strategies in the Postwar Japanese Antiwar Film.” Electronic Journal of Contemporary Japanese Studies, vol. 13, no. 4, 2013, www.japanesestudies.org.uk/ejcjs/vol13/iss4/briciu.html. 


\section{Lieffers | Juvenilia, Hiroshima, and the Politics of Peace}

Broderick, Mick, and Junko Hatori. "Pica-don: Japanese and American Reception and Promotion of Hideo Sekigawa's Hiroshima." The Atomic Bomb in Japanese Cinema: Critical Essays, edited by Matthew Edwards, McFarland, 2015, pp. 7787.

Bronson, Adam. One Hundred Million Philosophers: Science of Thought and the Culture of Democracy in Postwar Japan. U of Hawai'i P, 2016.

Buchholz, Petra. "The Second World War and Autobiography in Japan. Tales of War and the 'Movement for One's Own History' (Jibunshi)." Controlling Time and Shaping the Self: Developments in Autobiographical Writing since the Sixteenth Century, edited by Arianne Baggerman, Rudolf Dekker, and Michael Mascuch, Brill, 2011, pp. 197-213.

Caruth, Cathy. Introduction. Trauma: Explorations in Memory, edited by Caruth, Johns Hopkins UP, 1995, pp. 1-12.

Caruth, Cathy. Unclaimed Experience: Trauma, Narrative, and History. Baltimore: Johns Hopkins UP, 1996.

Cave, Peter, and Aaron William Moore. "Historical Interrogations of Japanese Children amid Disaster and War, 1920-1945." Japanese Studies, vol. 36, no. 3, 2016, pp. 287-98.

Centeno Martin, Marcos P. "The Limits of Fiction: Politics and Absent Scenes in Susumu Hani's Bad Boys (Furyōshōnen, 1960): A Film Re-Reading through Its Script." Journal of Japanese and Korean Cinema, vol. 10, no. 1, 2018, pp. 1-15.

Children of Hiroshima. Directed by Kaneto Shindo, Japan Teachers' Union, 1952.

Constitution of Japan. 1947. Prime Minister of Japan and His Cabinet, japan.kantei. go.jp/constitution_and_government_of_japan/constitution_e.html

Dower, John W. Embracing Defeat: Japan in the Wake of World War II. W. W. Norton, 1999.

Dust jacket copy. Children of the A-Bomb, edited by Arata Osada. Uchida Rokakuho, 1959.

Figal, Gerald. "How to jïbunshi: Making and Marketing Self-Histories of Shōwa among the Masses in Postwar Japan." The Journal of Asian Studies, vol. 55, no. 4, 1996, pp. 902-33.

Frühstück, Sabine. Playing War: Children and the Paradoxes of Modern Militarism in Japan. U of California P, 2017.

G., J. “Gembaku No Ko (Children of Hiroshima), Japan, 1953.” Montbly Film Bulletin, vol. 22, no. 252, 1955, pp. 69-70.

Hiraoka, Satsuki. "The Ideology and Practices of 'Seikatsu-Tsuzurikata': Education by Teaching of Expressive Writing." Educational Studies in Japan: International Yearbook, no. 6, 2011, pp. 21-31.

Hiroshima. Directed by Hideo Sekigawa, Japan Teachers' Union, 1953.

"Hiroshima: 70 Years after the A-bombing: A-bomb Films, Manga Stories Reach Beyond National Borders." Chugoku Shimbun, 18 December 2014, 


\section{JJS December (202I) Special Issue: Juvenilia, Trauma, and Intersectionality}

www.hiroshimapeacemedia.jp/?bombing=hiroshima-70-years-after-the-abombing-a-bomb-films-manga-stories-reach-beyond-national-borders.

"Hiroshima: 70 Years after the A-bombing: Paper Monuments 3." Chugoku Shimbun, 10 February 2015, www.hiroshimapeacemedia.jp/?bombing=2017-179.

"Hiroshima for Global Peace" Plan Joint Project Executive Committee. Hiroshima's Path to Reconstruction. Hiroshima Prefecture and the City of Hiroshima, 2015, hiroshimaforpeace.com/en/wpcontent/uploads/sites/2/2019/09/188742.pdf.

Hook, Glenn D. "Censorship and Reportage of Atomic Damage and Casualties in Hiroshima and Nagasaki." Bulletin of Concerned Asian Scholars, vol. 23, no. 1, 1991, pp. 13-25, doi: 10.1080/14672715.1991.10413159.

Jacobs, Robert. “Attacking Children with Nuclear Weapons: The Centrality of Children in American Understandings of the Bombings of Hiroshima and Nagasaki." W ar and Childhood in the Era of the Two World Wars, edited by Mischa Honeck and James Marten, German Historical Institute and Cambridge UP, 2019, pp. 267-82.

Lifton, Robert J. "The Bomb.” New York Review of Books. 1 February 1963, www.nybooks.com/articles/1963/02/01/the-bomb/.

Lowenstein, Adam. Shocking Representation: Historical Trauma, National Cinema, and the Modern Horror Film. Columbia UP, 2005.

Namba, Kenji. 'Book 'Children of the Atomic Bomb' marks 60th year of publication.” Chugoku Shimbun, 18 May 2011, www.hiroshimapeacemedia.jp/?p=20260.

Olsen, Stephanie. "The History of Childhood and the Emotional Turn." History Compass, vol. 15, no. 11, 2017, e12410, doi: 10.1111/hic3.12410.

Orr, James J. The Victim as Hero: Ideologies of Peace and National Identity in Postwar Japan. U of Hawai'i P, 2001.

Osada, Arata. "Appendix II-Compiler's Letter to the Writers." Children of the ABomb, edited by Osada, translated by Jean Dan and Ruth Sieben-Morgen, Uchida Rokakuho, 1959.

Osada, Arata. "Prof. Osada's Preface." Children of Hiroshima, edited by Osada. Harper Colophon, 1982.

Osada, Arata, ed. Children of Hiroshima. Harper Colophon, 1982.

Osada, Arata, ed. Children of the A-Bomb: The Testament of the Boys and Girls of Hiroshima. Translated by Jean Dan and Ruth Sieben-Morgen, G. P. Putnam's Sons, 1963.

Osada, Arata, ed. Children of the A-Bomb, translated by Jean Dan and Ruth SiebenMorgen. Tokyo: Uchida Rokakuho, 1959.

Robertson, Leslie. "Changing Models of Juvenilia: Apprenticeship or Play?” English Studies in Canada, vol. 24, no. 3, 1998, pp. 291-98, Project Muse, doi: 10.1353/esc.1998.0004. 


\section{Lieffers | Juvenilia, Hiroshima, and the Politics of Peace}

Russell, Bertrand. "A Statement from Bertrand Russell about Children of the ABomb." Dust jacket endorsement. Children of the A-Bomb, edited by Arata Osada, translated by Jean Dan and Ruth Sieben-Morgen, G. P. Putnam's Sons, 1963.

Satoh, Tomoyuki. "Children of the A-Bomb: I." Bulletin of Concerned Asian Scholars, vol. 10, no. 2, 1978, p. 28, doi: 10.1080/14672715.1978.10409080.

Shibata, Yuko. Producing Hiroshima and Nagasaki: Literature, Film, and Transnational Politics. U of Hawaici P, 2018.

Tashiro, Akira. "Hiroshima Memo: U.S. President and Japanese Prime Minister Should Listen to the Voices of Hiroshima's Children." Chugoku Shimbun, 25 November 2009, www.hiroshimapeacemedia.jp/?p=19939.

Uchida, Hitoshi. "Publisher's Note." Children of the A-Bomb, edited by Arata Osada, Uchida Rokakuho, 1959.

U.S. Department of Energy. "The Atomic Bombing of Hiroshima." The Manhattan Project: An Interactive History, www.osti.gov/opennet/manhattan-projecthistory/Events/1945/hiroshima.htm.

Yoneyama, Lisa. Hiroshima Traces: Time, Space, and the Dialectics of Memory. U of California P, 1999.

Zwigenberg, Ran. Hiroshima: The Origins of Global Memory Culture. Cambridge UP, 2014.

Zwigenberg, Ran. "Hiroshima Castle and the Long Shadow of Militarism in Postwar Japan." War, Tourism, and Modern Japan. Spec. issue of Japan Review, no 33, 2019, pp. 195-218. 